\title{
How Sustainable Farming and Food Technologies have Created the New Farm to Table Industry
}

\author{
Richard J. Mills Jr. \\ Robert Morris University
}

This research project deals with the new food consumption issues facing the United States government, consumers, the restaurant industry, and the general public. Reportedly, the sustainability food practices and farm to table industry represents 10\% of the country's economy. Capitalizing on the importance of this sector, the Green Restaurant Association developed several environmental guidelines and studies to help restaurants in their sustainable practices: energy efficiency, food conservation, water efficiency, food procurement, food distribution, consumer's green dining habits recycling, and composting. Under these new guidelines, restaurants can direct their operations towards profitable restaurant sustainability, consumer food distribution and newly created food marketing themes. This research will address the overall current trends in the new farm to table industry and the overall impact on modern food cultures. Several on-site food service operations are sustaining and advancing their efforts to be eco-friendly. This research looks to Universities, restaurants, and community co-ops in an examination of the sustainability options facing these new communities. In addition, a close look at the sustainability efforts in the United States is examined to show how the terms "grass roots" and "Sufficient" applies literally to one's own neighborhood.

Keywords: Agricultural Sustainability, Food Technologies, Farm Families, Community Agriculture, Grassroots Sustainability.

\section{INTRODUCTION}

The term sustainability has become so widely used in the food service industry that many may think it is the new "tell all" trend for success. It has been applied to a number of activities that gloss over its moral imperative; it has become the new meaning of environmental and foodservice enlightenment. Sustainability advances a food service philosophy of good will that brings together a new meaning to the justification of care and service responsibility. Sustainability has been used historically in other contexts or schools of thought with various meanings such as politically feasible, economically feasible, socially enlightened, consistent with neoconservative small government dogma and with liberal principles that outline justice, fairness, and morally desirable. With all this in mind one would begin to wonder or even ponder how the term sustainability has taken on such a trendy marketing and profit driven component within the food serve industry. Out of this food phenomenon many new industries know as farm to table or sustainable agriculture has emerged on the economic front. 


\section{THE HOTEL INDUSTRY: CURRENT TRENDS}

Most hotel companies have sustainability or social responsibility on top of their priorities. Marriott publishes a "sustainability report" every two years that highlight ethics and human rights, Marriott and society, Marriott and the environment such as energy and waste and green buildings. Marriott expects their hotels to focus on five global issues: poverty alleviation, the environment, community, workforce development, the well-being of children, and global diversity and inclusion.

Marriott encourages all of their hotels to embrace the concept "Spirit to S.E.R.V.E". Serve stands for shelter and food, environment, readiness for hotel careers, vitality of children, and embracing global diversity and inclusion. Hotels are given the freedom to work with a local business or partner with a larger organization such as Children's Miracle Network. Some examples of projects that our hotel has worked on this year are Habitat for Humanity, planting flowers for Neville green, working with a national foreign exchange organization (CCI) to hire foreign exchange students while on their summer breaks, working with Feed the Children to provide food to those in need, cleaning up local parks, donating blankets to Animal Friends, donating blood, assisting with local universities for mock interviews, and raising money for Children's Hospital. Marriott also works with the National Green Building Council and ENERGYSTAR to develop sustainable or "green buildings".

Franchise companies are taking the lead to build environmentally friendly hotels that through design and construction can reduce or even eliminate negative environmental impacts. The Courtyard by Marriott Settler's Ridge which opened September 2010 is the first Courtyard branded hotel prototype built from the ground up that will earn a LEED certification. Concord Hospitality is the management company and has taken several steps to ensure this hotel is "green" such as the exterior skin, heating and cooling, plumbing fixtures and construction material. Hotels traditionally use asphalt paving for their parking lots, but this hotel uses a combination of concrete paving. This helps sustain natural temperature in the surrounding area because of the elimination of heat absorption by the sun. The hotel purchased plants that are locally grown that require less water and the irrigation system has special rain sensor technology which will use less water than ordinary heads.

HVAC systems in this hotel will not have to run overtime to maintain insulation due to the exterior insulation system encased in a fluid applied air/water barrier to prevent water leaking in from the exterior skin. The hotel uses water efficient toilets, showerheads, and faucets which will save up $30 \%$ more water than a standard hotel. There are sensors in the room that will determine if the room is occupied and then adjust to the proper temperature. When the guest leaves, the rooms will revert to the set-point temperature.

The swimming pool is not your typical chlorine pool, rather is treated with sodium chloride (salt pool). Through the process of electrolysis, the sodium chloride produces liquid chlorine. Guests love these because they do not have "red eyes", the salt pool does is therefore a softer water and not discolor their swim suits, and of course there is not a strong odor of chlorine.

The Courtyard has a hybrid van used for guest transportation as well as having a few prime parking spaces that are designated for hybrid vehicles only. They offer recycling in the rooms and in all of the public areas and use eco friendly cleaning and pest products. The millions of Marriott branded pens used each year are now made from $74 \%$ biodegradable material. Ecolab has a product line of all eco-friendly cleaning supplies to assist hotels who choose to be a greener hotel.

Marriott hired Paul Gotzman as the Vice President of Food and Beverage Sustainability and Denise Naguib, Corporate Director of Environmental programs. I imagine each hotel group has this position created for continuous improvement of food and beverage initiatives. Mr. Gotzman was responsible for the new Courtyard F\&B concept of "the bistro". The outdated breakfast buffet has gone by the wayside for the new bistro concept. This has the feel of a "fast casual" dining restaurant such as Panera with a Starbucks in the bar area.

This new Courtyard by Marriott as well as all new builds has the bistro concept. The food is fresh and made to order rather than sitting at the buffet over a period of time. The bistro concept requires china and silverware versus paper plates and disposable utensils as the Fairfield Inn brand does. Guest's order 
from menu boards suspended from the ceiling and can also enjoy their favorite Starbuck's latte made from a trained hotel employee. The restaurant must also post calorie information on all of their menu boards. To keep the bistro fresh, there are seasonal promotions that all Courtyards must abide to. The Fall 2010 promotion includes Pumpkin Spice lattes, warm apple cranberry cobbler, and apple cranberry oatmeal to name only a few.

\section{EXPLORING SUSTAINABILITY IN AGRICULTURE}

Sustainability in agriculture is best told through real-life stories of farmers who are developing sustainable farming systems. Their approaches are varied and are applied according to the size and type of farm. Sustainable agriculture is based on many different goals and encompasses multiple strategies in operations, environment, and community involvement. The primary goals of sustainable agriculture include:

- Providing a more profitable farm income

- Promoting stable, prosperous farm families and communities

- Promoting environmental stewardship, including

○ Protecting and improving soil quality

- Reducing dependence on non-renewable resources, such as fuel and synthetic fertilizers and pesticides, and

- Minimizing adverse impacts on safety, wildlife, water quality and other environmental resources

\section{Profitability}

The profits gained from growing organic grains and produce are a bonus for the farmer. The farmer spends less to grow vegetables and therefore, enhance the profits for the crop. One farmer in the Midwest claims that in spite of the demanding labor requirements of growing organic, the cost of pesticides and fertilizers is eliminated. Organic products also sell for much more and thus, out-weigh the costs of labor.

\section{Environmental Strategies}

A farmer also engages in crop rotation to enhance the production of nitrogen and nitrogen up-take in the soil. These practices discourage weed growth and crowding from weeds in the garden

\section{Community, Outreach, Quality of Life}

The sustainable practices in farming ultimately affect the entire community: farmers and consumers share in the rewards of sustainability. A Midwest farmer works closely with the local university, cooperating on a research project on organic conversion. This practice is growing throughout the world as farmers, universities, and consumers wreak the benefits of sustainability in agriculture.

\section{HISTORICAL PERSPECTIVE AND ADVANCEMENT OF SUSTAINABILITY}

Sustainability is a word that is applied to various elements of a changing environment. The concept of sustainability has received much attention in the public domain and also within the college segment in recent years. From conservation to organic gardening, the consumer is frequently refreshed by an ongoing discussion on the impact of the environment and our everyday needs. This essay will address the history of sustainability; university curriculums and sustainability; restaurants and sustainability; ecofriendly initiatives; and sustainability in our own back yard, Pittsburgh, Pennsylvania.

The roots of sustainability science are directly attributed to Gilbert F. White who passed away in October, 2006 at his Colorado home at the age of 94 . He was once viewed as a radical, but now, his work has developed awareness. Unfortunately, this has not been translated into action; in many parts of the world, individuals have hampered the progress that was envisioned by White. Through teaching, writing, public service, and charitable undertakings, White began his mission as early as 1930. At this time, his 
concerns were not unlike those of today: human control of the natural environment. White's doctoral thesis began the conversation, Human Adjustment to Floods; this investigation questioned the warrant of large-scale water diversion as proposed by the government. The Tennessee Valley Authority, the Army Corps of engineers, and the Bureau of Reclamation were observed by thousands of individuals; these accomplishments were questioned by White as short-sighted public bodies, and imposing major constructions. White claimed that adaptability was the key to long term sustainability and encouraged current generations to adapt ourselves to the limits of biophysical systems (Cohen, ejournal.nbil.org). This idea opened the door to further investigation and study, and although it has taken many decades, scholars are beginning to discuss adaptability. Many universities and government agencies now proceed along the parameters of White's vision.

\section{Sustainability and Development}

Sustainability and the subject of food, hospitality, and tourism have become linked through various academic endeavors. Arizona State University (ASU) and its new Tempe-based School of Sustainability is the first of its kind in the world. Their emphasis includes a variety of related coursework in water quality, urban growth, and scarcity problems. ASU is offering interested students a broad-spectrum education with its master's degree and $\mathrm{Ph}$. D. programs. The doctorate program will be able to lead others in research and provide adaptive solutions to specific sustainability and its challenges (Blanchet, Feb. 2008). The government website includes the following as a description of what is happening in the field of sustainability:

"Sustainable development marries two important themes: that environmental protection does not preclude economic development and that economic development must be ecologically viable now and in the long run. Common use of the term "sustainability" began with the 1987 publication of the World Commission on Environment and Development report, Our Common Future. Also known as the Brundtland Report, this document defined sustainable development as "development that meets the needs of the present without compromising the ability of future generations to meet their own needs." This concept of sustainability encompasses ideas, aspirations and values that continue to inspire public and private organizations to become better stewards of the environment and that promote positive economic growth and social objectives. The principles of sustainability can stimulate technological innovation, advance competitiveness, and improve our quality of life" (www.gov.epa).

Gilbert F. White nurtured many of the principles that precipitate the rise of the contemporary concept of sustainable development (Cohen, 2006). In 1952, he called for industrialized countries to help developing nations formulate conservation strategies to further economic development. White was a Quaker and maintained an untiring interest in voluntary service and domestic and foreign humanitarian assistance; his early work was the forerunner of the Peace Corps. Robert Hinshaw's 2006 biography documents White's life and his many contributions as the earliest expert on sustainability

There are many reasons for consumers to be concerned with sustainability, and thus, the impact of resources is not only that of food and other consumable goods. Sustainability is important to all areas of the world including tropical landscapes as they still harbor hundreds of globally threatened species that cannot survive anywhere else (Meyers et. al. 2000) Ecosystems in natural environments are important to inhabitants as they are protective and furnish people with sustainable vegetation. For example, impoverished people may be undermined through deforestation, land degradation, and pollution (Alger, 2006). The unintended consequences of rural development policies may leave the remaining landscapes less capable of supporting those who remain (Chomitz, 2006).

The discussion continues as we look to our immediate environment and how we are impacted by conservation and green space. Everyone is familiar with zoning and its impact or lack of impact on our immediate residences, parks, or local common areas. Some communities reject regulation while others 
have worked to establish internal zoning for community use of resources. While good intentions are evident, enforcement of regulations may be problematic for some communities. Internal zones have become more participatory and transparent, while the legal status of the parks means that property rights over extractive uses within the established zones remains uncertain (Alger, 2006).

To understand how our local regulations may be significant, it is imperative that we look to those out of our immediate scope. Several areas around the world have been impacted by cleared forests within the protected areas; Indonesia inhibits agricultural use because their legal status impedes access to credit. The removal of protected status creates incentives for further speculation in the conversion of public or communal lands. This is used as an example to create a vision of the global significance of sustainability and how all corners of the earth impact other regions in a global sustainable environment. Global policymakers and strategic planners face difficult choices about future energy sources and how they will power cities; business; and transport systems. Sustainable energy and mobility are closely coupled with the supply chain for all economic sectors. Over the last two decades, awareness of sustainability has increased among government, industry, and the general public. Urban and industrial development has been impacted and increased important strategic issues for companies in all industries (Fiksel, 2006).

\section{UNIVERSITIES AND CHANGE OF PERSPECTIVE}

\section{On Campus Gardens: Hospitals and Universities}

On-campus gardens are great for education and marketing foodservice departments look for ways to extend their operation's reach beyond the cafeteria, and on-campus gardens provide this opportunity. Gardens provide education in nutrition and sustainability. Gardens offer a place for people to congregate and reflect. In addition, gardens are wonderful tools to connect people throughout a community while uniting them behind a common cause. Many hospitals and universities are joining the sustainability conversation:

- Fletcher Allen Health Care, Burlington, Vermont has a healing garden for patients and grows its own produce; there is a 12-foot trellis for cucumbers and a section of the garden is for flowering plants;

- Lebanon Community Schools, Lebanon, Oregon, has a raised bed garden; students work together with adults and learn responsibility. The garden has helped school nutrition and encouraged community involvement;

- University of Maryland, College Park, Maryland has a roof top garden; the first garden was 16 square feet, but now has grown as the students expand their knowledge and interest. Part of the work is environmental, showing how plants can be grown from recycled containers. Compost is provided from food scraps and collected rainwater;

- Bayer Corp., Pittsburgh, PA, grows their garden in containers; they primarily grow herbs such as basil, parsley, cilantro, tarragon, and purple basil. The herb garden is a collaborative effort between several departments at Bayer, including dining services, the wellness department, the maintenance department and the Bayer Material Science Sustainability Community Council; and

- Baltimore City Public Schools, Baltimore, MD, has a 33-acre farm and 30 school gardens. Tony Geraci, director of food and nutrition suggests that you start small and build a plan for direction. The local Department of Agriculture office and local gardening clubs helped start the garden. Also, local nurseries and garden centers are a great place to get connected to local resources (Food-Service Director, August 15, 2010).

\section{Other University Projects}

The grand state of affairs globally impacts us all and calls us to ask: "What can we do?" and "How does this affect us personally?" The answers are available through study and awareness; the results may be derived from education and a change of perspective at the university level. Arizona State University is 
joined by many universities to prepare students with information to take to disciplines in a wide range of topics. The following is partial list of courses offered at ASU: International Development and Sustainability; State Land Workshop; Human Dimensions of Sustainability; earth Systems Engineering and Management; Sustainable Resource Allocation; Urban Growth; Water Quality and Society; and Advanced Earth Systems Engineering and Management. This list of courses demonstrates the depth of education and diversity associated with the subject of sustainability. The quality and quantity of courses offered at one university is only the beginning of what is available to students of sustainability, the environment, conservation, and quality of life improvement.

The Acterra Award for Sustainability was created by Stanford University to recognize businesses with holistic sustainability approaches and practices. Stanford University's dining focuses on environmentally sound campus policies. The Stanford University executive director, Rafi Taherian, says that "sustainability is a business strategy. It is good social policy, but done, right, it also reduces costs. If you have to spend additional money to support the program, it isn't truly sustainable." Taherian graduated from the Culinary Institute of America and initiated sustainability efforts when he first joined Stanford in 1996; his focus was on ways to make the kitchen work more efficiently, switching out equipment to reduce energy usage and installing infared cooking equipment, velocity-controlled hoods and combination ovens. He claims that sustainability begins with conservation and not with food acquisition (www.food-management.com, Oct. 2007).

Taherian's approach has been to focus on top quality food concepts and presentations while maintaining a concept of staying lean and working smart. Various mechanisms are in place including development of an infrastructure on campus. 3,600 students who live in particular residence halls are required to purchase a meal plan; this is approximately $95 \%$ of the students. Taherian relies on able management and engages institutional statesmanship when operating realities to adjust to longstanding traditions without generating protest. "You've got to enlist students as partners in your endeavors," Taherian states. He acknowledges that students are the largest critics. Traditional breakfast service is offered at two dining halls, with continental fare available; on weekends, one closes down while two latenight, meal plan-accessible options offering fresh organic salads and fruit, pizza, grab-and-go snacks, smoothies and desserts stay open until 2 AM. The sustainability sidebar became a student celebration; Taherian organized them to plant and maintain organic, community herb and vegetable gardens at each residence hall. Dining services now use many of the fresh herbs in its own culinary efforts, and students, under supervision, sell other bounty at an on-campus, outdoor Produce Stand every Friday (Freidland and Lawn, 2007).

Hofstra University is providing a fine-dining venue as they had a grand opening held inside the ballroom; they featured Tuscan pizza topped with gorgonzola, poached pears and prosciutto, Mediterranean kebabs, and ice cream, in lemon-poppy, sundried cherry and goat cheese-chocolatechipotle flavors. Authenticity is the key word in this menu selection and is reflected at the University of Rochester in the campus dining services' approach to sustainability initiatives. "We're introducing procedures such as local purchasing and evaluating our carbon footprint in a sensible way that meets many criteria including cost quality including cost and quality. We're very sensitive about designing a composting program, for example, and don't want to be guilty of green washing which Cam Schauf defines as just doing things that look green but aren't" (www.nrn.com February 25, 2008).

For the past two years, Cornell University Dining has made sustainability a focus for the Ithaca community. The Moosewood Restaurant has serviced customers in the local community with an emphasis on fresh food with a healthy and $100 \%$ sustainable restaurant experience. The Moosewood's most popular sandwiches and salads received positive feedback from customers; the sandwiches are made from locally grown products. The venue has been utilizing biodegradable materials including biodegradable utensils (FSD mag.com). 


\section{CURRENT TRENDS IN THE INDUSTRY PROVE RESTAURANTS PROFIT FROM SUSTAINABILITY}

Students and universities have joined the cultural conversation with many commercial enterprises. One area of great concern is the hotel industry as guests demand a green environment with greater responsibility from hotels and restaurants.

As restaurants and institutions continue the evolving process toward sustainability, this year's International Hotel/Motel \& Restaurant Show hosted 35,000 hospitality professionals; the debut of the Green Restaurant Association Pavilion will help visitors adapt to new eco-friendly concepts (restaurants \& Institutions, Oct. 15, 2007). Considering that this is hotel industry's annual version of the one-stop shop, the $92^{\text {nd }}$ annual IH/M\&RS at the Jacob K. Javits Convention Center managed to provide a glimpse of the major themes and trends in environmental sustainability and technology.

Boutique lodging was the focus in which a panel comprised of young designers weighed in on topics such as branding and technology and discussed how they are designing for the next generation of boutique guests. The panel focused on a blend of the five senses or natural elements: earth, water, air, fire and space. "Senses are very powerful because that is what creates a lasting memory" (Hotel Business, Dec. 2007).

Design is only a part of the total package for the hotel industry; in addition, the guestroom category is of the utmost importance. Wilson Associates was awarded for the design of the Kempinski Hotel in Dubai, United Arab Emirates; Skidmore, Owings \& Merrill LLP won tin the suite category for the Peaks Resort \& Spa in Telluride, Co. Wilson Associates also won in the spa category for the Four Seasons Hotel Hong Kong. In keeping with the environmental focus, five green product awards were awarded; in addition, there were awards for technology.

Statistics show hotels, motels, and restaurants that sustainability is of interest to half of U. S. consumers. Information Resources Inc. claims that at least one of four key features, eco-friendly packaging, organic status, eco-friendly status or fair-treatment status, is a consideration of $50 \%$ of consumers (Restaurants \& Institutions, Feb. 2008). Fresh food and in particular fresh fish is a concern for many chefs as popular fish become scarce; alternative species are now part of culinary trend. "I've just contracted a group of fishermen to get barracuda for me out of the waters of Tobag," says Barton Seaver the chef of Hook in Washington, D. C." (www.nrn.com, November 5, 2007). According to Bret Thorn, chefs are in a quandary about fish because for years people ate what was considered to be an endless supply of cod. Now consumers have to be confident in making alternative decisions. Alison Barshak, the chef-owner of Alison at Blue Bell in Blue Bell, PA., has similar philosophy: "We just call our fish person and ask what's local." Joh Besh, executive chef of Restaurant August in New Orleans, recalls shrimping in the South and also, the variety they caught: flounder, sheephead, tripletail. Besh cooks tripletail in a Cajun-style court bouillon with onion, bell peppers, celery, tomato, allspice and other seasonings. He is now serving brown eel, which he cuts into pieces, poaches, fillets and then makes into a brand to be stuffed in ravioli. Alternative seafood species are definitely being selected by many chefs in a variety of cities.

Sam King, CEO of King's Seafood Company, a restaurant and distribution operation, is trying to change the notion that sustainable food is more expensive. The view that sustainability is an environmental issue is of the utmost importance to the California chain of eleven casual King's Fish

Houses. King helped launch the Sustainable Seafood Forum that advises restaurateurs and the public about seafood choices that are sustainable and affordable. King's doesn't sell grouper, orange roughy, Pacific cod, Chilean sea bass, or other endangered species, but includes farmed and wild salmon, farmraised trout, shad, whitefish and mussels. "If the only salmon I served was from certified wild fisheries, half of my customers couldn't afford it. We source from farms in Chile that use advanced agricultural techniques" (Foodservice Buyer, September 2007).

Technology company executives discussed major industry trends at the $12^{\text {th }}$ International Foodservice Technology Exposition and acknowledged sustainability and environmental concerns as key to the decision-making process among suppliers in the decade ahead. "When it comes to sustainability, all of us 
here... are concerned about our impact on the environment," said Steve Garland, the national sales manager for Epson System Device Group (www.nrn.com Oct. 29, 2007). The question: "How do we run profitable businesses and still be food stewards to the environment?" These questions and others are of great concern to many green areas and environmentally safe endeavors. One answer is that on-site industry sustainability; this is evidenced at Stanford University and other resource based venues.

As we approach a new way of thinking about resources, the local supermarket comes into view and how local produce, milk, and other foods can be utilized to furnish product to the hospitality industry including hotels and restaurants. The size of the supermarket chains and their procurement power makes them more obvious targets in the environmental debate than restaurants (Caterer \& Hotelkeeper, 2007). Another challenge is that of how much carbon gas your products generate. In addition, the questions posed for restaurants are whether or not units even open for business if a metropolitan area needs to ration clean water. Balancing energy spent, water consumed, coupled with calories, sodium and saturated fats for each menu item can be taxing. All of the arenas must be entered to answer the final question of sustainability and cost effectiveness.

\section{SUSTAINABILITY FROM GRASSROOTS}

The Pittsburgh market, like many others around the globe, are exploring new and innovative ideas and implementing them for consumers. The Green Harvest sustainable food system project was developed by the Greater Pittsburgh Community Food Bank in 1991; this was developed to help low income people while facilitating agricultural sustainability, economic development, and urban beautification in communities it serves. The project combines environmental concerns; community economic development, and direct service to low-in-come people in the following ways:

- Asa sustainable agriculture program and environmental enterprise that has resulted in new jobs (especially in low-income urban communities);

- By promoting accessible, well-planned garden space and retaining the community focus in urban/public housing areas; and

- By providing a multitude of opportunities for citizen and youth involvement in sustainable agriculture and environmental issues(Sustainability in Action).

The money to support the program comes from CSA shareholder fees, sales to Farm Stands, aeed and produce sales, and foundation support that includes funding from an anonymous local foundation, the Center for Rural Pennsylvania, and Share Our Strength. Community Development Block Grant funding helped secure needed equipment for the farm.

Harvest Sensations offers fresh produce, fresh seafood, fresh chicken and fresh dairy and are dedicated to servicing customers with the highest quality fresh products available to all food service outlets. This Pittsburgh based company is part of Paragon/Monteverde and has a commitment to customers to guarantee every order with the freshest and best products available. For 26 years, Harvest Sensations has built a strong foundation with specialty food experience from the garden to the kitchens of many fine restaurants. President, Dean Simon shares his passion for quality food with you through Harvest Sensations. "Along with our team of only the finest farmers, we proudly offer you delicious seasonal produce sourced weekly" (www.harvestsensations.com).

Richard DeShantz is a well know chef in the Pittsburgh area and approaches his food procurement with zest and vigor as he arrives at The Strip District every morning. Chef DeShantz shops smart because he picks up what's fresh; he's also not afraid to ask for suggestions or about how certain things are prepared or served. He is a learning chef as he delivers his expertise. He has certain rules to follow when purchasing his food items:

- Rule One: Don't be afraid to ask questions.

- Rule Two: Carve out time to shop.

- Rule three: Buy what's in season.

- Rule four: don't overlook your "home" grocery store. 
DeShantz chooses spices, oils, and butters according to the dishes he is serving. He prefers to cook with peanut oil due to its high smoking point and neutral flavor. He also uses it to cut the intense flavor of sesame oil. The Strip District is the perfect haven for professional and amateur chefs in Pittsburgh, and offers a fresh alternative to other choices in a local market (The Table, Autumn 2007).

Blackberry Meadows, in Natrona Heights (near Pittsburgh, PA), is being acquired by Slippery Rock graduates who believe sustainability can sustain them. Greg Boulos, 31, Jen Montgomery, 29, Heath Gamache, 35, and Greg's brother Dave, 30, are taking the chance of their young lives as they acquire Blackberry Farms. Jack and Dale Duff have been operating the farm all summer under a lease/purchase agreement. The farm's Community Supported Agriculture program (CSA), a veggies-by-subscription program, is the oldest organic one in Western Pennsylvania. The agreement hinged on Blackberry's 100 plus customers continuing to receive their weekly boxes of fresh produce. "The place was untended, strangling in brambles. We named it Blackberry Meadows and set to clearing it, just the two of us with a small tractor" (Pittsburgh Quarterly, Fall 2007). The four partners graduated from Slippery Rock's unusual and entrepreneurial Masters of Science in Sustainable Systems. Each brings a unique component to the farm and the object is sustainability. One partner, Jen, has farmed on three continents; she can discuss permaculture in New Zealand and can also, build a stone wall, cook on a wood stove and herd sheep. She managed a CSA in Harper's Ferry, and at Slippery Rock directed the school's farm and farm market. She credits "organic bluebloods" in Pittsburgh: Don Kretschmann, operator of one of the largest organic CSA's in the country; and Mindy Schwartz of Garden Dreams. Mindy farms Wilkinsburg vacant lots and is a partner in the big-thinking foundation, Grow Pittsburgh, that spearheads many urban agriculture projects.

On an extremely local scale, we are neighboring a newly developed farm: Shared Acres. Dwayne and Renee Bauknight of Cork Bocktown Road in Clinton, PA, spoke about their newest venture. They are farming nearly 40 acres of newly purchased land they have named Shared Acres. Dwayne does most of the farming, holding a Bachelor's Degree from Robert Morris University, a master's in Engineering Management from Rober Morris University, and is pursuing his Ph.D. at West Virginia University. When speaking with Dwayne, you cannot miss the depth of knowledge and enthusiasm he has for sustainable gardening. "We will focus on growing bio-dynamically, with no industrial pesticides or chemicals; we let nature do its thing." Dwayne answered my question about deer and he claims that he grows enough for both humans and wildlife and has had no problems. His farm is a co-op where shareholders will come by the farm and pick up a basket of vegetables that will eventually incorporate fruits, herbs, and flowers. Each basket will include a regular mix of salad greens and seasonal vegetables.

In 2002, Evan and Jodi Verbanic started a garden on a small plot of land at their home in Crafton, PA. The also grow vegetables, herbs, and flowers, and launched a small-scale organic Community Supported Agriculture (CSA) project that they named Urban Roots. By 2005, they purchased 35 acres names Cherry Valley near Burgettstown, PA. Cherry Valley has impacted the retail and food service scene as well as the corporate partnership with Parkhurst Dining Services, a division of the Eat n' Park Hospitality Group. They delivered weekly farm shares to Bayer Corporation and Dick's Sporting Goods for their employees. Cherry Valley has impacted the retail and food service scene as well. In addition, they plan on participating in farmers' markets in: Bethel Park, Sewickley, and Washington. "We're pleased to provide what the public wants, and what they meant more of is what's organic, fresh, nutritious, and high quality" (Jeannette, 2007).

\section{SUSTAINABILITY BEGINS AT HOME}

Roselea Farm was built in 1905 and was utilized primarily as a residence for one hundred years; some of those years the farm housed dairy cows, and at other times, the acreage was used for growing vegetables and grain. In 2003, a greenhouse was added to the property to grow flowers as a commercial crop; in addition, fencing was updated to contain a herd of meat goats. The greenhouse is operated by a local grower who has expanded from growing annual flowers to perennial flowers, herbs, and vegetables. The goats are taken to a local meat market for members of the community to purchase. This form of 
sustainability has taken hold as Roselea Farm Greenhouse has expanded its resources and made product available to local residents.

The grower has developed a mixed green salad mixture that is sold to a nearby restaurant. The Hyeholde Restaurant is an upscale restaurant, and like many other specialty eateries, the chef finds locally grown produce to be very attractive to customers. The mixed greens or micro greens are grown approximately 10 months of the year while other vegetables, such as peppers, are grown for 6 months. Another local restaurant, The Sea Shell, buys peppers for stuffing and also, is interested in the procurement of greens. The vegetable business is growing as the need for sustainable products increases and demand leads the way; sustainability does begin at home, and Roselea Farm is our home of sustainability.

\section{REFERENCES}

Alger, K. (2006). Human response to environmental decline at the forest frontier, Fall 2006, 2(2).

Retrieved from http://ejournal.nbil.org

Blanchet, K. D. (2008, February). Sustainability, 1(1).

Campbell, C. (2007). Table Magazine, Autumn.

Chomitz, K. (2006). At Loggerheads? Agricultural Expansion, Property Reduction And Environment in the Tropical Forests. Washington DC: World Bank.

Cohen, M. J. (2006). The roots of sustainability science: a tribute to Gilbert F. White. Sustainability: Science, Practice, \& Policy, Fall, 2(2). Retrieved from http:ejournal.nbil.org

Core, P. (2007, September). Fishing for Answers. Food Service Buyer.

Fiksel, J. (2006). Sustainability and resilience: toward a systems approach. Retrieved from http://ejournal.nbil.org.

Friedland, A., \& Lawn, J. (2007, October). Food-Management.

Food Service Magazine. (2007, March 15).

Foodservice Magazine. (2008, February 15).

Harvest Sensations. (n.d.). Retieved from www.harvestsensations.com $/ \mathrm{menuV} 1 \mathrm{html}$

Hinshaw, R. (2006). Living With Nature's Extremes: The Life of Gilbert Fowler White. Boulder: Johnson Books.

Hotel Business. (2007, December 7).

Jeannette, P. (2007). Allegheny West Magazine.

Marriott Franchise Source-the Bistro

Marriott's Sustainability Report 2008-2009

Meyers, N., Mittermeier, R., Mittermeier, C. da Fonscca, G., \& Kent, J. (2000). Biodiversity hotspots for conservation priorities. Nature, 403(6772), 853-58.

Nations's Restaurant News. (2006, November 27).

Phillips, V. (2007). Pittsburgh Quarterly, Fall.

Restaurants \& Institutions. (2006, January).

Restaurants \& Institutions. (2006, February).

Restaurants \& Institutions. (2007, October 15).

Statement of LEED Summary by Tim Osiecki, Executive VP of Development Concord Hospitality

Thorn, B. (2007, November 5). A Good Catch. Culinary Currents. 